\title{
Public Health: Champion of Food and Nutritional Security in an Insecure World
}

\begin{abstract}
When it comes to nutrition, like most middle-income countries, Cuba is equally haunted by shadows of an undernourished past and forebodings of an overweight future. This dilemma is the country-level expression of a tough global reality: the world's empty stomachs and empty calories result from the same skewed constellation of international economic and trade policies. Speaking of the current and unprecedented food, fuel, climate and financial crises, World Health Organization (WHO) Director-General Margaret Chan comments: "...they are the result of massive failures in the international systems that govern the way nations and their populations interact. In short: they are the result of bad policies...(in which) economic interests trump health concerns time and time again."[1]
\end{abstract}

On the brink, as always, are poor countries and already disadvantaged populations. Thus, by December last year, 40 million more people were pushed into hunger worldwide, reaching 923 million, the vast majority in developing nations. The main, but not only, culprit: higher food prices. Landless households run by women were the most vulnerable of all, introducing gender, land distribution and urbanization as key predictors of who will go hungry.

Even those countries that have apparently cleared the hurdle of widespread hunger still face the peril of poor nutrition, as their national policies, social determinants and cultural traditions interact with the inequitable and unpredictable global order.

Cuba is a case in point. In 2008, its bill for food imports soared to US $\$ 2.2$ billion from $\$ 1.5$ billion the year before, due primarily to rising commodity prices, more restrictive US food export regulations, and hurricane recovery efforts. The three hurricanes that swiped the island in 2008 caused damages estimated at $20 \%$ of the country's GDP, including $\$ 5$ billion alone in losses to crops, livestock and inputs to food production. These blows, together with lower prices for Cuba's main exports, have squeezed the economy to a point unseen since the crash of the 1990s.[2]

If domestic policies in agriculture, urbanization, salaries, food production and import selection are figured in, the nutrition matrix becomes more complex. For example, already $75 \%$ of the Cuban population lives in urban areas, and the country imports $80 \%$ of its food. Since the early 1960 s, the government has sold a portion of essential foodstuffs at highly subsidized prices. Yet, ineffective land use, pay and marketing policies have resulted in insufficient food and food choices to satisfy demands of 11 million Cubans, and President Raúl Castro has referred to periodic shortages of fruits, vegetables and other healthy basic foodstuffs. To boost production and decrease import dependency, the government has embarked on one of the largest land use reforms in 50 years, placing nearly an additional 2 million acres at the disposal of small private farmers. Such small-scale farmers and cooperatives already work one-third of the farmland, their productivity proven by the fact that they produce two-thirds of the nation's vegetables and other crops.

Similar "correctives" are being evaluated across the policy spectrum but have yet to impact areas such as imports of junk foods, quality of offerings or preparation methods in national fast-food chains, or the ubiquity of sweets and sweeteners in this "land of sugar". Which brings us to social and cultural determinants of population nutrition: as this issue indicates, the Cuban predilection remains strong for fried foods, red meat, and sugars and starches of all kinds, eschewing vegetables in particular. National studies show that even if salaries were raised to accommodate all desires, preferences would remain the same, at least in the foreseeable future (Cubans Team up for Better Nutrition).

The result is that foods that are abundant, accessible and in demand are not always healthy; and healthy foods are not always available, accessible or desired by consumers. This in turn results in the dual dilemma we referred to above: pockets of undernourishment (e.g., iron-deficiency anemia in small children and pregnant women) and rising rates of overweight and obesity in the general population.

Enter Cuba's universal public health system, faced with the daunting job of leading efforts to turn this situation around. Its role is paramount in epidemiological studies and surveillance, providing baselines and trends to inform directions for policy change (Overweight, Obesity, Central Adiposity and Associated Chronic Diseases in Cuban Adults). Its specialized institutions, national programmatic scope and clinical networks are central to strategy design, prevention, and assisting the most vulnerable (The Public Health Sector and Nutrition in Cuba). Its scientific expertise is critical to developing sound nutritional guidelines and public education (Dietary Reference Intakes for the Cuban Population, 2008). And its research is key to discovering how nutritional innovation may interact with disease (Ma-Pi 2 Macrobiotic Diet Intervention in Adults with Type 2 Diabetes Mellitus).

But above all, public health decision-makers, professionals and advocates at all levels are the champions who can sway government and lead the multi-sector charge to put health and nutrition at the top of every policy agenda, so that health concerns-to paraphrase Dr Chan-finally trump all others.

This issue also offers a preliminary look at a pioneering study on $\mathrm{Cu}$ ban centenarians (Counting to 100: A First Look at Cuba's National Centenarian Study) and recent research on a Cuban treatment for diabetic foot (Heberprot- $P$ ) — the latter a preview of our first 2010 issue focusing on Cuban therapies. Finally, we publish an opinion piece on developing-country research priorities (The Role of Disease-Specific Research) as a welcome to participants in the 2009 Forum for Global Health Research this November in Havana. -1 -

\section{The Editors}

1. Chan M. Keynote address at the 12th World Congress on Public Health. Istanbul, Turkey. 27 April 2009 [monograph on the Internet]. Geneva: WHO; 2009 [cited 2009 Oct 9]. Available from: http://www.who.int/dg/speeches/2009/ steadfast midst perils 20090428/en/.

2. Cuba. In: Estudio económico de América Latina y el Caribe 2008-2009 [monograph on the Internet]. Santiago: The United Nations Economic Commission for Latin America and the Caribbean; 2009 Jul [cited 2009 Oct 9]. Available from: http://www.eclac.org/cgi-bin/getProd.asp?xml=/publicaciones/ xml/4/36464/P36464.xml\&xsl=/de/tpl/p9f.xsl\&base=/tpl/top-bottom.xslt 